\title{
The Third Edition of the Civil Engineering Body of Knowledge: An Update and Overview
}

\section{Dr. Kenneth J. Fridley, University of Alabama}

Kenneth J. Fridley is the Senior Associate Dean for the College of Engineering at The University of Alabama. Prior to his current appointment, Fridley served as Professor and Head of the Department of Civil, Construction and Environmental Engineering at the University of Alabama. Dr. Fridley has been recognized as a dedicated educator throughout his career and has received several awards for his teaching efforts, including the ExCEEd (Excellence in Civil Engineering Education) Leadership Award in 2010. At the University of Alabama, Fridley has led efforts to establish several new programs including new undergraduate degree programs in construction engineering, architectural engineering and environmental engineering, a departmental Scholars program allowing highly qualified students an accelerated program to earn their MSCE in addition to their BS degree, the interdisciplinary "Cube" promoting innovation in engineering, and the cross-disciplinary MSCE/MBA and MSCE/JD dual-degree programs.

\section{Dr. Decker B. Hains, Western Michigan University}

Dr. Decker B. Hains is a Master Faculty Specialist in the Department of Civil and Construction Engineering at Western Michigan University. He is a retired US Army Officer serving 22 years on active duty with the US Army Corps of Engineers and taught at the United States Military Academy at West Point (USMA). He earned a Bachelor of Science degree in Civil Engineering from USMA in 1994, Master of Science degrees from the University of Alaska Anchorage in Arctic Engineering in 1998 and Missouri University Science \& Technology in Civil Engineering in 1999, and a PhD in Civil Engineering from Lehigh University in 2004. He is a registered Professional Engineer in Michigan.

\section{Dr. Brock E. Barry P.E., United States Military Academy}

Dr. Brock E. Barry, P.E. is an Associate Professor and Mechanics Group Director in the Department of Civil \& Mechanical Engineering at the United States Military Academy, West Point, New York. Dr. Barry holds a Bachelor of Science degree from Rochester Institute of Technology, a Master of Science degree from University of Colorado at Boulder, and a $\mathrm{PhD}$ from Purdue University. Prior to pursuing a career in academics, Dr. Barry spent 10-years as a senior geotechnical engineer and project manager on projects throughout the United States. He is a licensed professional engineer in multiple states. Dr. Barry's areas of research include assessment of professional ethics, teaching and learning in engineering education, nonverbal communication in the classroom, and learning through historical engineering accomplishments. He has authored and co-authored a significant number of journal articles and book chapters on these topics.

\section{Dr. Kristen L. Sanford Bernhardt, Lafayette College}

Dr. Kristen Sanford Bernhardt is chair of the Engineering Studies program and associate professor of Civil and Environmental Engineering at Lafayette College. Her expertise is in sustainable civil infrastructure management and transportation systems. She teaches a variety of courses including sustainability of built systems, transportation systems, transportation planning, civil infrastructure management, and Lafayette's introductory first year engineering course. Dr. Sanford Bernhardt serves on the American Society of Civil Engineers' Committees on Education and Faculty Development and the Transportation Research Board Committee on Education and Training. She previously has served as vice-chair of the ASCE Infrastructure Systems Committee, chair of the ASEE's Civil Engineering Division, and a member of the Transportation Research Board committees on Artificial Intelligence and Advanced Computing, Asset Management, and Emerging Technology for Design and Construction. She received her Ph.D. and M.S. from Carnegie Mellon University, and her B.S.E. from Duke University.

\section{Ms. Leslie Nolen CAE, American Society of Civil Engineers}

Leslie Nolen, CAE, serves as director, educational activities for the American Society of Civil Engineers. She brings over 20 years of association management experience to her work with ASCE's Committee on Education on issues of importance to the undergraduate and graduate level education of civil engineers. 


\section{The Third Edition of the Civil Engineering Body of Knowledge: An Update and Overview}

\section{Introduction}

In October, 2016, the American Society of Civil Engineers (ASCE) launched the Body of Knowledge 3 Task Committee (BOK3TC), and in 2017 an update on the task committee's work was provided at the ASEE Annual Conference and Exposition in Columbus, $\mathrm{OH}$ [1]. That presentation and paper provided a summary of the findings of the committee following critical reviews of published literature and an initial survey of constituents. Based on those findings, the BOK3TC determined that a Third Edition of the Civil Engineering Body of Knowledge (BOK3) was warranted (not a forgone conclusion when the task committee was formed by ASCE) and outlined a series of next steps to develop the BOK3. The primary purpose of this paper is to once again update the civil engineering community on the progress of the BOK3TC and to present a first draft of the BOK3 outcomes.

\section{Committee Approach}

The charge to the BOK3TC was to critically review published literature regarding the future of engineering, other disciplines, and civil engineering practice; proactively solicit constituent input; evaluate the ASCE BOK2 [2]; determine if a third edition of the Civil Engineering Body of Knowledge report is warranted at this time; and if warranted, develop the BOK3 report. The BOK3TC is employing a five-phase process to fulfill its charge.

Phase I: The first phase was reported in the 2017 [1] and focused on reviewing available literature, conducting a formal survey of constituents, and determining whether a new edition of the BOK was needed.

Phase II: Based on the results of the first phase, the committee determined a third edition of the BOK was necessary. The second phase involved developing possible new outcomes and revising existing BOK2 outcomes based on information from the first phase, conducting an internal survey of all BOK3TC members (full and corresponding), and developing pre-first draft outcome rubrics for the BOK3.

Phase III: The third phase, focused on critically assessing the pre-first draft BOK3 outcome rubrics and developing preliminary drafts of explanations for each of the outcomes. Phase III also included seeking input from constituent groups on the predraft BOK 3 outcomes through a second formal survey.

Phase IV: The BOK3TC is currently in phase four, which includes developing the first draft of the BOK3 and finalizing first drafts of the explanations for each of the outcomes. Phase IV also involves obtaining input from constituency groups through formal surveys and presentations to various constituency groups.

Phase V: The fifth and final phase will include a full evaluation of all constituency input resulting from Phase IV and the development of the final draft of the BOK3 report. It is expected that the final BOK3 report will be published in early 2019.

This paper focuses on the second and third phases, as well as part of the fourth phase, including the first draft of the BOK3 outcome rubrics with levels of achievement. 


\section{Development of Pre-Draft BOK3 Outcome Rubrics}

Based on the literature review in Phase I, the BOK3TC identified a number of potential changes to the BOK2. This included possible changes in both methods/approach and in outcomes.

The BOK2 is uses Bloom's Taxonomy [3] to express outcome rubrics, which include outcome statements for each of the levels of achievement. The committee considered other educational taxonomies, including the Anderson and Krathwohl revised Bloom's Taxonomy [4]. After considerable discussion, the BOK3TC decided any advantages that other taxonomies may offer should be weighed against the confusion that result from changing the basic foundation for constructing the BOK outcome rubrics. The committee decided to continue using Bloom's original taxonomy based on both its simplicity in how it is constructed and its similarity to the traditional engineering problem solving process.

In addition to considering potential changes to the twenty-four outcomes included in the BOK2, the BOK3TC identified a number of outcomes that may be applicable and important to civil engineers, but either were not included in or were, perhaps, under-emphasized in the BOK2. These possible new outcomes included critical thinking, analytical thinking, information literacy, interpersonal skills, safety, engineering economics, creativity and innovation, information technology, legal aspects, systems engineering, civil learning and engagement, and licensure.

Finally, the BOK3TC also considered the possible inclusion of both the cognitive and affective domains of Bloom's Taxonomy in the BOK3 [5, 6]. The cognitive domain, which was used in the BOK2, describes the development of intellectual skills, ranging from the simple recollection of specific facts to the integration and evaluation of complex ideas and concepts [3]. The affective domain, which was referenced in an appendix of the BOK2 but was not formally part of the BOK2 outcomes, describes an individual's level of internalization or sense of value for human experience, to include their degree of acceptance or rejection of a concept, process or phenomenon [7].

To fully assess the appropriateness of potential changes to the existing BOK2 outcomes, possible new outcomes, and formally including the affective domain (in addition to the cognitive domain), the BOK3TC developed preliminary drafts of all existing and potential new outcomes. This included revisions to all 24 BOK2 outcomes and 12 potential new outcomes in the cognitive domain, as well as development of outcomes in the affective domain for 19 of the 36 total outcomes.

The BOK3TC conducted a comprehensive evaluation of the preliminary draft rubrics. An internal committee survey was used, which required committee members to answer the following questions for each outcome:

1. What percentage of civil engineers should achieve some level of competency in this area? (all, most, approximately half, some, few to none)

2. For those who are expected to possess this competency (based on response to first question), what is the minimum level of achievement? 
3. If all civil engineers are expected to possess this competency (regardless of response to first question), what is the minimum level of achievement?

4. Should this outcome be integrated with any other outcome? If so, please explain.

Note that the BOK is defined as being applicable to all civil engineers. The purpose of the first two questions was to allow the committee members completing the survey the ability to identify certain outcomes that may be important to the profession, but not necessarily required of each and every civil engineer. This, in turn, provided the BOK3TC a different perspective that may be helpful in determining whether a particular outcome is or is not included in the BOK3, as well as whether integration or combination of outcomes should be considered.

Using the results of the internal committee survey, the BOK3TC discussed, critically evaluated, and debated the appropriateness of each of the outcome rubrics. The committee also evaluated the full suite of outcome rubrics, considering relationships between and among outcomes. Through this evaluation process, the BOK3TC reduced the number of total outcomes from thirty-six, with nineteen having rubrics in both the cognitive and affective domains, to twenty-one outcomes, with seven having rubrics in both the cognitive and affective domain. This set of twenty-one outcomes was defined as a pre-first draft of the BOK3 outcome rubrics.

\section{Constituent Input}

Upon completion of the pre-draft of the BOK3 outcome rubrics, the BOK3TC proactively sought constituent group input through a formal survey. The pre-draft rubric was provided and respondents were asked to provide the following input for each of the 21 outcomes:

1. The minimum level of achievement appropriate for all civil engineers as they enter into the practice of civil engineering at the professional level or "not applicable" if the outcome should not be included in the BOK.

2. Explanation for any outcomes that were identified as not applicable.

3. Suggestions for improving any outcomes

4. Recommendations for anything that may be missing from the outcomes.

The BOK3TC actively sought constituent input and promoted the survey through a variety of mechanisms available through ASCE. A total of 141 responses were received to the survey. The summary of the demographics of the second survey takers is provided in Tables 1a, b, and c. While the BOK3TC hoped for a higher response rate (the committee received 303 responses to its first constituent group survey), the committee recognized that the time required to complete the second survey was significant and may have contributed to a lower response rate. The committee also noted that the demographic breakdown was very similar between the two surveys. Considering all this, the survey provided meaningful and valid input.

The BOK3TC considered the results of the survey, including both the quantitative data and qualitative responses, noting that none of the outcomes were identified as being not appropriate for the BOK. Over the course of a two-day face-to-face meeting, the committee 
Table 1a. Summary of Second Survey Respondent Demographics (Employer)

\begin{tabular}{|r|c|c|}
\hline Current Employer & Count & Percent \\
\hline Government agency & 50 & $35.5 \%$ \\
\hline Academic/university & 37 & $26.2 \%$ \\
\hline Private-practice engineering consulting firm & 32 & $22.7 \%$ \\
\hline Other (please specify) & 6 & $4.3 \%$ \\
\hline Multi-discipline corporation & 4 & $2.8 \%$ \\
\hline Retired & 4 & $2.8 \%$ \\
\hline Sole proprietor & 3 & $2.1 \%$ \\
\hline Military & 2 & $1.4 \%$ \\
\hline Association/non-profit & 2 & $1.4 \%$ \\
\hline Contractor/builder & 1 & $0.7 \%$ \\
\hline Total & 141 & $100 \%$ \\
\hline
\end{tabular}

Table 1b. Summary of Second Survey Respondent Demographics (Experience)

\begin{tabular}{|r|c|c|}
\hline Years of Experience & Count & Percent \\
\hline $1-5$ & 13 & $9.2 \%$ \\
\hline $6-10$ & 18 & $12.8 \%$ \\
\hline $11-15$ & 16 & $11.3 \%$ \\
\hline $16-20$ & 13 & $9.2 \%$ \\
\hline $21-25$ & 12 & $8.5 \%$ \\
\hline$>25$ & 69 & $48.9 \%$ \\
\hline Total & 141 & $100 \%$ \\
\hline
\end{tabular}

Table 1c. Summary of Second Survey Respondent Demographics (Education)

\begin{tabular}{|r|c|c|}
\hline Years of Experience & Count & Percent \\
\hline Bachelors & 48 & $34.0 \%$ \\
\hline Masters & 42 & $29.8 \%$ \\
\hline Doctorate & 51 & $36.2 \%$ \\
\hline Total & 141 & $100 \%$ \\
\hline
\end{tabular}

debated and developed a consensus regarding, for each outcome, the minimum level of achievement appropriate for all civil engineers as they enter into the practice of civil engineering at the professional level.

In addition, the committee discussed and developed a preliminary typical pathway to fulfillment of the BOK. Both by definition and in recognition of civil engineering being a profession of practice, the fulfillment of the BOK requires both formal education and mentored experience. As with previous editions of the BOK, formal education includes two components: undergraduate education (UG) and post-graduate education (PG). Post graduate education may or may not lead to a graduate-level degree. Note that the BOK2 
Table 2a. Summary of Second Survey Responses (Cognitive Domain)

\begin{tabular}{|l|c|c|c|c|c|c|c|}
\hline Cognitive Domain & $\begin{array}{c}\text { Level } \\
1\end{array}$ & $\begin{array}{c}\text { Level } \\
2\end{array}$ & $\begin{array}{c}\text { Level } \\
4\end{array}$ & $\begin{array}{c}\text { Level } \\
5\end{array}$ & $\begin{array}{c}\text { Level } \\
6\end{array}$ & $\mathrm{~N} / \mathrm{A}$ \\
\hline Mathematics & $0.7 \%$ & $1.4 \%$ & $22.7 \%$ & $40.4 \%$ & $17.0 \%$ & $17.7 \%$ & $0.0 \%$ \\
\hline Natural Sciences & $2.1 \%$ & $8.5 \%$ & $30.5 \%$ & $30.5 \%$ & $16.3 \%$ & $11.3 \%$ & $0.7 \%$ \\
\hline Social Sciences & $6.4 \%$ & $19.9 \%$ & $40.4 \%$ & $17.0 \%$ & $10.6 \%$ & $4.3 \%$ & $1.4 \%$ \\
\hline Humanities & $7.1 \%$ & $25.5 \%$ & $34.0 \%$ & $14.9 \%$ & $10.6 \%$ & $5.0 \%$ & $2.8 \%$ \\
\hline Materials Science & $0.7 \%$ & $5.0 \%$ & $30.2 \%$ & $38.1 \%$ & $12.2 \%$ & $12.9 \%$ & $0.7 \%$ \\
\hline Engineering Mechanics & $0.0 \%$ & $2.1 \%$ & $25.7 \%$ & $38.6 \%$ & $19.3 \%$ & $14.3 \%$ & $0.0 \%$ \\
\hline $\begin{array}{l}\text { Experimental Methods and } \\
\text { Data Analysis }\end{array}$ & $2.1 \%$ & $10.6 \%$ & $19.1 \%$ & $36.9 \%$ & $19.1 \%$ & $12.1 \%$ & $0.0 \%$ \\
\hline $\begin{array}{l}\text { Critical Thinking and } \\
\text { Problem Solving }\end{array}$ & $0.7 \%$ & $2.1 \%$ & $12.1 \%$ & $24.3 \%$ & $23.6 \%$ & $36.4 \%$ & $0.7 \%$ \\
\hline Project Management & $2.1 \%$ & $12.8 \%$ & $22.0 \%$ & $30.5 \%$ & $19.9 \%$ & $11.3 \%$ & $1.4 \%$ \\
\hline Engineering Economics & $4.3 \%$ & $4.3 \%$ & $31.9 \%$ & $29.8 \%$ & $19.9 \%$ & $9.2 \%$ & $0.7 \%$ \\
\hline Risk and Uncertainty & $2.9 \%$ & $13.6 \%$ & $27.9 \%$ & $25.7 \%$ & $17.1 \%$ & $12.1 \%$ & $0.7 \%$ \\
\hline $\begin{array}{l}\text { Breadth in Civil } \\
\text { Engineering Areas }\end{array}$ & $2.1 \%$ & $9.2 \%$ & $30.5 \%$ & $27.7 \%$ & $21.3 \%$ & $7.1 \%$ & $2.1 \%$ \\
\hline Design & $0.7 \%$ & $5.7 \%$ & $18.6 \%$ & $25.7 \%$ & $27.9 \%$ & $20.0 \%$ & $1.4 \%$ \\
\hline Technical Specialization & $3.6 \%$ & $7.9 \%$ & $20.0 \%$ & $35.0 \%$ & $18.6 \%$ & $15.0 \%$ & $0.0 \%$ \\
\hline Sustainability & $5.0 \%$ & $12.8 \%$ & $36.2 \%$ & $24.1 \%$ & $10.6 \%$ & $9.9 \%$ & $1.4 \%$ \\
\hline Communication & $3.5 \%$ & $6.4 \%$ & $26.2 \%$ & $20.6 \%$ & $26.2 \%$ & $17.0 \%$ & $0.0 \%$ \\
\hline Teamwork \& Leadership & $2.2 \%$ & $8.7 \%$ & $29.7 \%$ & $18.1 \%$ & $27.5 \%$ & $13.0 \%$ & $0.7 \%$ \\
\hline Attitudes & $1.4 \%$ & $7.1 \%$ & $35.5 \%$ & $15.6 \%$ & $20.6 \%$ & $11.3 \%$ & $8.5 \%$ \\
\hline Lifelong Learning & $4.3 \%$ & $9.9 \%$ & $28.4 \%$ & $19.1 \%$ & $22.7 \%$ & $15.6 \%$ & $0.0 \%$ \\
\hline Ethical Responsibility & $0.0 \%$ & $2.8 \%$ & $23.4 \%$ & $22.0 \%$ & $19.9 \%$ & $31.2 \%$ & $0.7 \%$ \\
\hline $\begin{array}{l}\text { Professional } \text { Responsibilities } \\
\text { S. }\end{array}$ & $3.5 \%$ & $9.2 \%$ & $17.0 \%$ & $20.6 \%$ & $21.3 \%$ & $27.0 \%$ & $1.4 \%$ \\
\hline
\end{tabular}


Table 2b. Summary of Second Survey Responses (Affective Domain)

\begin{tabular}{|l|c|c|c|c|c|c|}
\hline Affective Domain & $\begin{array}{c}\text { Level } \\
1\end{array}$ & $\begin{array}{c}\text { Level } \\
2\end{array}$ & $\begin{array}{c}\text { Level } \\
3\end{array}$ & $\begin{array}{c}\text { Level } \\
4\end{array}$ & $\begin{array}{c}\text { Level } \\
5\end{array}$ & N/A \\
\hline Sustainability & $8.0 \%$ & $17.4 \%$ & $37.0 \%$ & $26.8 \%$ & $6.5 \%$ & $4.3 \%$ \\
\hline Communication & $4.4 \%$ & $18.4 \%$ & $16.2 \%$ & $44.1 \%$ & $15.4 \%$ & $1.5 \%$ \\
\hline Teamwork and Leadership & $5.8 \%$ & $14.5 \%$ & $22.5 \%$ & $42.0 \%$ & $13.0 \%$ & $2.2 \%$ \\
\hline Attitudes & $4.3 \%$ & $10.9 \%$ & $26.8 \%$ & $38.4 \%$ & $13.8 \%$ & $5.8 \%$ \\
\hline Lifelong Learning & $5.8 \%$ & $17.5 \%$ & $25.5 \%$ & $32.1 \%$ & $16.8 \%$ & $2.2 \%$ \\
\hline Ethical Responsibility & $1.5 \%$ & $7.3 \%$ & $16.8 \%$ & $29.2 \%$ & $43.1 \%$ & $2.2 \%$ \\
\hline $\begin{array}{l}\text { Professional } \\
\text { Responsibilities }\end{array}$ & $2.9 \%$ & $8.0 \%$ & $26.1 \%$ & $28.3 \%$ & $33.3 \%$ & $1.4 \%$ \\
\hline
\end{tabular}

used " $\mathrm{B}$ " for baccalaureate degree and " $\mathrm{M} / 30$ " for master's degree or equivalent. The BOK2 also used "E" for experience, and the BOK3TC decided to use the term mentored experience (ME) to indicate the importance of mentorship to an early-career civil engineer.

The BOK3TC also introduced a new component to the typical pathway to fulfillment of the BOK: self-development (SD). This was done primarily as a result of introducing the affective domain for some of the outcomes. While formal education and mentored experience are appropriate and can be used to develop the knowledge and skills defined in the cognitive domain, the committee considered the need for personal commitment by each civil engineer to develop some of the outcomes, particularly the value systems that are required for the affective domain. Self-development requires a civil engineer to define needs and mechanisms to develop the associated knowledge, skills, and attitudes of the outcome, and to assess their own progress and fulfillment of the outcome. The committee only included SD as a component to fulfilment of affective domain rubrics; SD is not included in the cognitive domain.

\section{First Draft of BOK3 Outcome Rubrics}

In addition to considering the results of the survey, developing a consensus for the level of achievement for each outcome, and establishing a preliminary typical pathway to fulfillment, the BOK3TC created an editing task group that critically reviewed the outcome rubrics for consistency in wording, adherence to Bloom's Taxonomy, and any potential areas that may result in confusion or misinterpretation, while maintaining the intent of each outcome. This task group presented the full BOK3TC with its findings and a series of potential issues. The committee discussed the edited version of the rubrics and a series of proposals that were considered substantive changes to the intent of outcomes, and it approved the official first draft of the $\mathrm{BOK} 3$ outcome rubrics, including the preliminary typical pathway. The full first draft of the BOK3 outcome rubric is provided in Appendix I. 
In addition to, and perhaps more important than, the full BOK 3 outcome rubrics are expanded explanations for each outcome. The BOK3TC recognizes the need for clear justifications for each outcome, including what the outcome means, why the outcome is included in the BOK, and why the level of achievement is defined at the specified level. Explanations will be a primary part of the final BOK 3 report. Two examples of draft outcome explanations are provided in Appendix II.

Table 3 provides a summary of the evolution from the BOK2 to the first draft of the BOK3. The columns list the 24 BOK2 outcomes, the 36 pre-draft BOK 3 outcomes (which included all 24 BOK2 outcomes and 12 possible new outcomes, labeled a through 1), and the 21 first draft BOK3 outcomes. The rows are arranged based the order of the first draft BOK3 outcomes, thus the rows of BOK2 and pre-draft BOK3 columns are out of order.

\section{Next Steps}

The BOK3TC is currently in the fourth of five phases. Along with having developed the first draft of the BOK3 (see Appendix I), the committee has also finalized first drafts of the explanations for each of the outcomes (see Appendix II). With first drafts of both the rubrics and explanations completed, the BOK3TC again will be seeking input from constituency groups through formal surveys and presentations to various groups. Input will be sought regarding both the level of achievement and the typical pathway through both quantitative and qualitative methods. The fifth and final phase of the committee's work will include a full evaluation of all constituency input resulting from phase four and the development of the final draft of the full BOK3 report. It is expected that the final BOK3 report will be published in early 2019 . 
Table 3. Summary of BOK2, Pre-Draft BOK3, and First Draft BOK3 Outcomes.

\begin{tabular}{|c|c|c|}
\hline $\begin{array}{l}\text { BOK2 Outcomes } \\
\text { (February 2008) }\end{array}$ & $\begin{array}{l}\text { Pre-Draft BOK3 Outcomes } \\
\text { (September 2017) }\end{array}$ & $\begin{array}{l}\text { First Draft BOK3 Outcomes } \\
\text { (March 2018) }\end{array}$ \\
\hline (1) Mathematics & (1) Mathematics & (1) Mathematics \\
\hline (2) Natural Sciences & (2) Natural Sciences & (2) Natural Sciences \\
\hline (4) Social Sciences & (4) Social Sciences & (3) Social Sciences \\
\hline (3) Humanities & (3) Humanities & (4) Humanities \\
\hline (5) Materials Science & (5) Materials Science & Materials Science \\
\hline (6) Mechanics & (6) Mechanics & (6) Engineering Mechanics \\
\hline (7) Experiments & (7) Experiments & $\begin{array}{l}\text { (7) Experiment Methods \& } \\
\text { Data Analysis }\end{array}$ \\
\hline $\begin{array}{l}\text { (8) Problem Recognition \& } \\
\text { Solving }\end{array}$ & $\begin{array}{l}\text { (8) Problem Recognition \& } \\
\text { Solving }\end{array}$ & \multirow{2}{*}{$\begin{array}{l}\text { (8) Critical Thinking \& } \\
\text { Problem Solving }\end{array}$} \\
\hline & (a) Critical Thinking & \\
\hline \multirow[t]{2}{*}{ (13) Project Management } & (13) Project Management & (9) Project Management \\
\hline & (f) Engineering Economics & (10) Engineering Economics \\
\hline (12) Risk \& Uncertainty & (12) Risk \& Uncertainty & (11) Risk \& Uncertainty \\
\hline $\begin{array}{l}\text { (14) Breadth in Civil } \\
\text { Engineering Areas }\end{array}$ & $\begin{array}{l}\text { (14) Breadth in Civil } \\
\text { Engineering Areas }\end{array}$ & $\begin{array}{l}\text { (12) Breadth in Civil } \\
\text { Engineering Areas }\end{array}$ \\
\hline (9) Design & (9) Design & (13) Design \\
\hline (15) Technical Specialization & (15) Technical Specialization & (14) Technical Depth \\
\hline (10) Sustainability & (10) Sustainability & (15) Sustainability \\
\hline (16) Communication & (16) Communication & (16) Communication \\
\hline (20) Leadership & (20) Leadership & (17) Teamwork \& Leadership \\
\hline (21) Teamwork & (21) Teamwork & \\
\hline (23) Lifelong Learning & (23) Lifelong Learning & (18) Lifelong Learning \\
\hline \multirow[t]{5}{*}{ (22) Attitudes } & (22) Attitudes & (19) Professional Attitudes \\
\hline & (e) Safety & \multirow{5}{*}{$\begin{array}{l}\text { (20) Professional } \\
\text { Responsibilities }\end{array}$} \\
\hline & (g) Creativity \& Innovation & \\
\hline & (i) Legal Aspects & \\
\hline & (1) Licensure & \\
\hline \multirow{2}{*}{$\begin{array}{l}\text { (24) Professional \& Ethical } \\
\text { Responsibility }\end{array}$} & \multirow{2}{*}{$\begin{array}{l}\text { (24) Professional \& Ethical } \\
\text { Responsibility }\end{array}$} & \\
\hline & & (21) Ethical Responsibilities \\
\hline $\begin{array}{l}\text { (11) Contemporary Issues \& } \\
\text { Historical Perspectives }\end{array}$ & $\begin{array}{c}\text { (11) Contemporary Issues \& } \\
\text { Historical Perspectives }\end{array}$ & \\
\hline (17) Public Policy & (17) Public Policy & \\
\hline $\begin{array}{l}\text { (18) Business \& Public } \\
\text { Administration }\end{array}$ & $\begin{array}{l}\text { (18) Business \& Public } \\
\text { Administration }\end{array}$ & \\
\hline \multirow[t]{7}{*}{ (19) Globalization } & (19) Globalization & \\
\hline & (b) Analytical Thinking & \\
\hline & (c) Information Literacy & \\
\hline & (d) Interpersonal Skills & \\
\hline & (h) Information Technology & \\
\hline & (j) Systems Engineering & \\
\hline & $\begin{array}{ll}\text { (k) Civil Learning \& } \\
\text { Engagement }\end{array}$ & \\
\hline
\end{tabular}




\section{References}

[1] Fridley, K.J., Hains, D.B., Nolen, L., Barry, B.E., Hartmann, B.L. (2017) "Is It Time for a Third Edition of the Civil Engineering Body of Knowledge (BOK)?" Proceedings of the 2017 ASEE Annual Conference \& Exposition, June 2017.

[2] Civil Engineering Body of Knowledge for the 21st Century: Preparing the Civil Engineer for the Future, Second Edition. (2008) American Society of Civil Engineers (ASCE), Reston, VA.

[3] Bloom, B.S., Englehart, M.D., Furst, E.J., Hill, W.H. and Krathwohl, D.R. 1956. Taxonomy of Educational Objectives, the Classification of Educational Goals, Handbook I: Cognitive Domain. David McKay Company, New York, NY.

[4] Anderson, L., and Krathwohl, D. A. (2001). Taxonomy for Learning, Teaching and Assessing: A Revision of Bloom's Taxonomy of Educational Objectives. New York: Longman.

[5] Hains, D.B., Fridley, K.J., Nolen, L. (2018) "Revising the Civil Engineering Body of Knowledge (BOK): The Application of the Cognitive Domain of Bloom's Taxonomy." Proceedings of the 2018 ASEE Annual Conference \& Exposition, June 2018.

[6] Dennis, N.D., and Hains, D.B. (2018) "Assessing the Civil Engineering Body of Knowledge in the Affective Domain." Proceedings of the 2018 ASEE Annual Conference \& Exposition, June 2018.

[7] Krathwohl, D. R., Bloom, B.S. and Masia, B.B. 1964. The Taxonomy of Educational Objectives: The Classification of Educational Goals. Handbook II: Affective Domain. David McKay Company, New York, NY. 


\section{Appendix I: First Draft BOK3 Outcome Rubrics}

The first draft of the BOK3 outcome rubrics included in this appendix are being used to seek constituent group input through a formal survey and presentations to various groups. 
First Draft of the BOK3 Cognitive Domain Rubric

\begin{tabular}{|c|c|c|c|c|c|c|}
\hline \multirow[b]{2}{*}{ Outcome } & \multicolumn{6}{|c|}{$\begin{array}{l}\text { Cognitive Domain Level of Achievement } \\
\text { The cognitive domain describes the development of intellectual skills, ranging from the simple recollection of } \\
\text { specific facts to the integration and evaluation of complex ideas and concepts. }\end{array}$} \\
\hline & $\begin{array}{l}\text { Level } 1 \\
\text { Remember } \\
\text { The ability to } \\
\text { remember previously } \\
\text { learned material. }\end{array}$ & $\begin{array}{c}\text { Level } 2 \\
\text { Comprehend } \\
\text { The ability to grasp the } \\
\text { meaning of learned } \\
\text { material. }\end{array}$ & $\begin{array}{c}\text { Level } 3 \\
\text { Apply } \\
\text { The ability to use } \\
\text { learned material in } \\
\text { new and concrete } \\
\text { situations. }\end{array}$ & $\begin{array}{c}\text { Level } 4 \\
\text { Analyze } \\
\text { The ability to break } \\
\text { down learned material } \\
\text { into its component } \\
\text { parts so that its } \\
\text { organizational } \\
\text { structure may be } \\
\text { understood. }\end{array}$ & $\begin{array}{l}\text { Level } 5 \\
\text { Synthesize } \\
\text { The ability to put } \\
\text { learned material } \\
\text { together to form a } \\
\text { new whole. }\end{array}$ & $\begin{array}{c}\text { Level } 6 \\
\text { Evaluate } \\
\text { The ability to judge the } \\
\text { significance and } \\
\text { importance of learned } \\
\text { material for a given } \\
\text { purpose. }\end{array}$ \\
\hline Mathematics & $\begin{array}{l}\text { Identify concepts } \\
\text { and principles of } \\
\text { mathematics, } \\
\text { including differential } \\
\text { equations and } \\
\text { numerical methods. } \\
\text { (UG) }\end{array}$ & $\begin{array}{l}\text { Explain concepts } \\
\text { and principles of } \\
\text { mathematics, } \\
\text { including differential } \\
\text { equations and } \\
\text { numerical methods. } \\
\text { (UG) }\end{array}$ & $\begin{array}{l}\text { Apply concepts and } \\
\text { principles of } \\
\text { mathematics, } \\
\text { including differential } \\
\text { equations and } \\
\text { numerical methods, } \\
\text { to solve civil } \\
\text { engineering } \\
\text { problems. (UG) }\end{array}$ & $\begin{array}{l}\text { Select appropriate } \\
\text { concepts and } \\
\text { principles of } \\
\text { mathematics to } \\
\text { solve civil } \\
\text { engineering } \\
\text { problems. (PG) }\end{array}$ & $\begin{array}{l}\text { Develop } \\
\text { mathematical } \\
\text { models to solve civil } \\
\text { engineering } \\
\text { problems. }\end{array}$ & $\begin{array}{l}\text { Assess } \\
\text { mathematical } \\
\text { models used to } \\
\text { solve civil } \\
\text { engineering } \\
\text { problems. }\end{array}$ \\
\hline Natural Sciences & $\begin{array}{l}\text { Identify concepts } \\
\text { and principles of } \\
\text { calculus-based } \\
\text { physics, chemistry } \\
\text { and at least one } \\
\text { other area of the } \\
\text { natural sciences. } \\
\text { (UG) }\end{array}$ & $\begin{array}{l}\text { Explain concepts } \\
\text { and principles of } \\
\text { calculus-based } \\
\text { physics, chemistry } \\
\text { and at least one } \\
\text { other area of the } \\
\text { natural sciences. } \\
\text { (UG) }\end{array}$ & $\begin{array}{l}\text { Apply concepts and } \\
\text { principles of } \\
\text { calculus-based } \\
\text { physics, chemistry } \\
\text { and at least one } \\
\text { other area of the } \\
\text { natural sciences, to } \\
\text { solve civil } \\
\text { engineering } \\
\text { problems. (UG) }\end{array}$ & $\begin{array}{l}\text { Select appropriate } \\
\text { concepts and } \\
\text { principles of natural } \\
\text { sciences to solve } \\
\text { civil engineering } \\
\text { problems. (PG) }\end{array}$ & $\begin{array}{l}\text { Integrate } \\
\text { appropriate } \\
\text { concepts and } \\
\text { principles of natural } \\
\text { sciences to solve } \\
\text { civil engineering } \\
\text { problems. }\end{array}$ & $\begin{array}{l}\text { Evaluate solutions } \\
\text { to civil engineering } \\
\text { problems involving } \\
\text { concepts and } \\
\text { principles of natural } \\
\text { sciences. }\end{array}$ \\
\hline
\end{tabular}




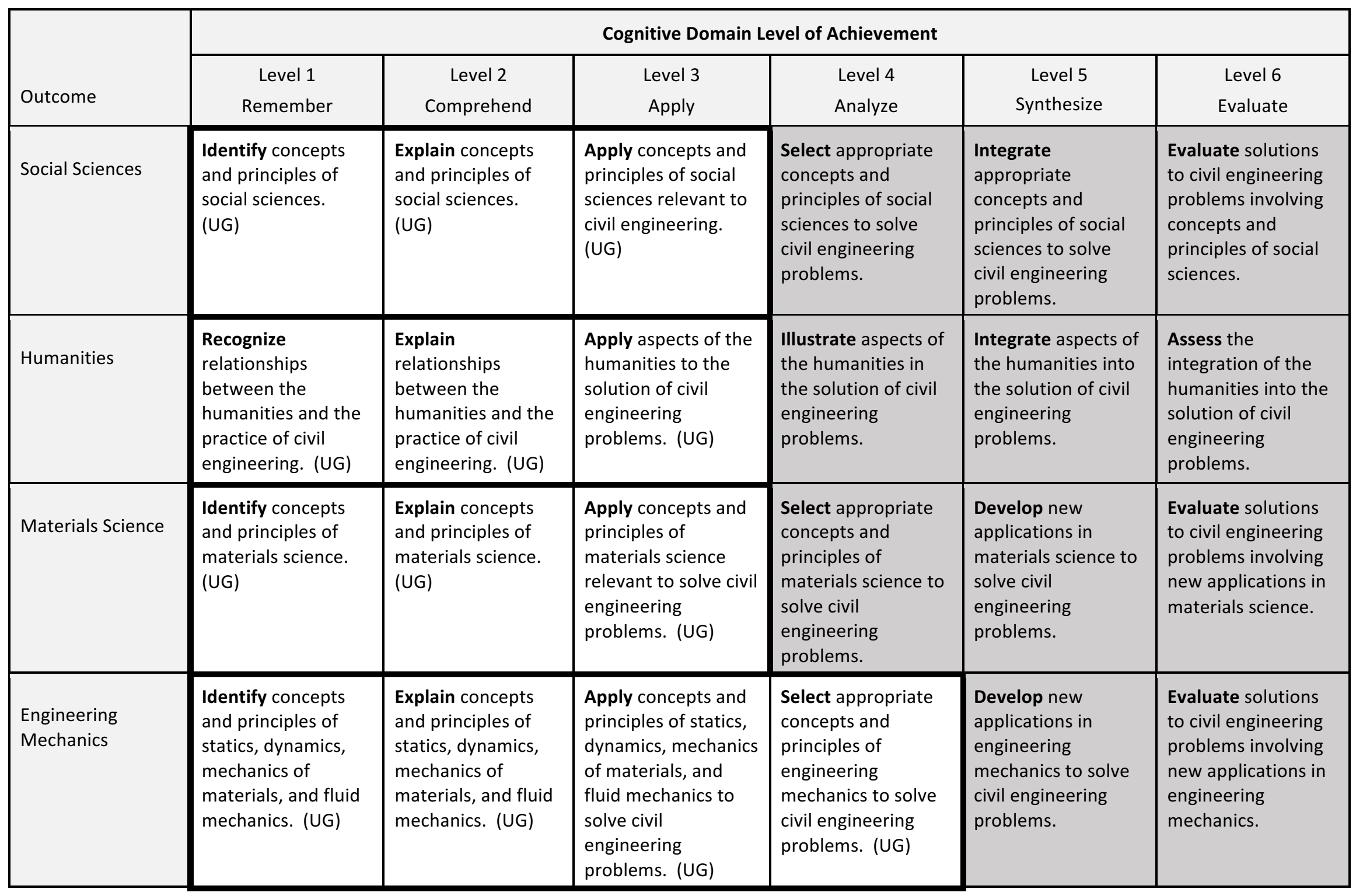




\begin{tabular}{|c|c|c|c|c|c|c|}
\hline \multirow[b]{2}{*}{ Outcome } & \multicolumn{6}{|c|}{ Cognitive Domain Level of Achievement } \\
\hline & $\begin{array}{c}\text { Level } 1 \\
\text { Remember }\end{array}$ & $\begin{array}{c}\text { Level } 2 \\
\text { Comprehend }\end{array}$ & $\begin{array}{l}\text { Level } 3 \\
\text { Apply }\end{array}$ & $\begin{array}{l}\text { Level } 4 \\
\text { Analyze }\end{array}$ & $\begin{array}{c}\text { Level } 5 \\
\text { Synthesize }\end{array}$ & $\begin{array}{c}\text { Level } 6 \\
\text { Evaluate }\end{array}$ \\
\hline $\begin{array}{l}\text { Experimental } \\
\text { Methods and Data } \\
\text { Analysis }\end{array}$ & $\begin{array}{l}\text { Identify the } \\
\text { procedures and } \\
\text { equipment } \\
\text { necessary to } \\
\text { conduct } \\
\text { experiments in at } \\
\text { least two technical } \\
\text { areas of civil } \\
\text { engineering. (UG) }\end{array}$ & $\begin{array}{l}\text { Explain the purpose, } \\
\text { procedures, } \\
\text { equipment, and } \\
\text { practical } \\
\text { applications of } \\
\text { experiments in at } \\
\text { least two technical } \\
\text { areas of civil } \\
\text { engineering. (UG) }\end{array}$ & $\begin{array}{l}\text { Conduct } \\
\text { experiments in at } \\
\text { least two technical } \\
\text { areas of civil } \\
\text { engineering, and } \\
\text { report the results. } \\
\text { (UG) }\end{array}$ & $\begin{array}{l}\text { Select appropriate } \\
\text { experiments, and } \\
\text { analyze the results } \\
\text { in the solution of } \\
\text { civil engineering } \\
\text { problems. (PG) }\end{array}$ & $\begin{array}{l}\text { Develop new } \\
\text { experimental } \\
\text { methods, and/or } \\
\text { integrate the results } \\
\text { of multiple } \\
\text { experiments for the } \\
\text { solution of civil } \\
\text { engineering } \\
\text { problems. }\end{array}$ & $\begin{array}{l}\text { Assess new } \\
\text { experimental } \\
\text { methods and/or the } \\
\text { results of multiple } \\
\text { experiments for the } \\
\text { solution of civil } \\
\text { engineering } \\
\text { problems. }\end{array}$ \\
\hline $\begin{array}{l}\text { Critical Thinking } \\
\text { and Problem } \\
\text { Solving }\end{array}$ & $\begin{array}{l}\text { Identify and define } \\
\text { a complex problem, } \\
\text { question or issue } \\
\text { relevant to civil } \\
\text { engineering. (UG) }\end{array}$ & $\begin{array}{l}\text { Explain the scope } \\
\text { and context of a } \\
\text { complex problem, } \\
\text { question or issue } \\
\text { relevant to civil } \\
\text { engineering. (UG) }\end{array}$ & $\begin{array}{l}\text { Formulate a set of } \\
\text { possible solutions to } \\
\text { a complex problem, } \\
\text { question or issue } \\
\text { relevant to civil } \\
\text { engineering. (UG) }\end{array}$ & $\begin{array}{l}\text { Analyze a set of } \\
\text { possible solutions to } \\
\text { a complex problem, } \\
\text { question or issue } \\
\text { relevant to civil } \\
\text { engineering. (ME) }\end{array}$ & $\begin{array}{l}\text { Develop the most } \\
\text { appropriate solution } \\
\text { to a complex } \\
\text { problem, question } \\
\text { or issue relevant to } \\
\text { civil engineering. } \\
\text { (ME) }\end{array}$ & $\begin{array}{l}\text { Assess solutions to } \\
\text { complex problems, } \\
\text { questions or issues } \\
\text { relevant to civil } \\
\text { engineering. }\end{array}$ \\
\hline $\begin{array}{l}\text { Project } \\
\text { Management }\end{array}$ & $\begin{array}{l}\text { Identify concepts } \\
\text { and principles of } \\
\text { project } \\
\text { management. (UG) }\end{array}$ & $\begin{array}{l}\text { Explain concepts } \\
\text { and principles of } \\
\text { project } \\
\text { management. (UG) }\end{array}$ & $\begin{array}{l}\text { Formulate } \\
\text { components of } \\
\text { project } \\
\text { management plans } \\
\text { for complex civil } \\
\text { engineering } \\
\text { projects. (UG) }\end{array}$ & $\begin{array}{l}\text { Analyze } \\
\text { components of } \\
\text { project } \\
\text { management plans } \\
\text { for complex civil } \\
\text { engineering } \\
\text { projects. (ME) }\end{array}$ & $\begin{array}{l}\text { Integrate } \\
\text { components into } \\
\text { complete project } \\
\text { management plans } \\
\text { for complex civil } \\
\text { engineering } \\
\text { projects. }\end{array}$ & $\begin{array}{l}\text { Evaluate project } \\
\text { management plans } \\
\text { for complex civil } \\
\text { engineering } \\
\text { projects. }\end{array}$ \\
\hline $\begin{array}{l}\text { Engineering } \\
\text { Economics }\end{array}$ & $\begin{array}{l}\text { Identify concepts } \\
\text { and principles of } \\
\text { engineering } \\
\text { economics. (UG) }\end{array}$ & $\begin{array}{l}\text { Explain concepts } \\
\text { and principles of } \\
\text { engineering } \\
\text { economics. (UG) }\end{array}$ & $\begin{array}{l}\text { Apply concepts and } \\
\text { principles of } \\
\text { engineering } \\
\text { economics in the } \\
\text { practice of civil } \\
\text { engineering. (ME) }\end{array}$ & $\begin{array}{l}\text { Select appropriate } \\
\text { concepts and } \\
\text { principles of } \\
\text { engineering } \\
\text { economics for the } \\
\text { practice of civil } \\
\text { engineering. }\end{array}$ & $\begin{array}{l}\text { Integrate } \\
\text { engineering } \\
\text { economics analyses } \\
\text { in the practice of } \\
\text { civil engineering. }\end{array}$ & $\begin{array}{l}\text { Appraise the } \\
\text { effectiveness of } \\
\text { engineering } \\
\text { economic analyses } \\
\text { in the practice of } \\
\text { civil engineering. }\end{array}$ \\
\hline
\end{tabular}




\begin{tabular}{|c|c|c|c|c|c|c|}
\hline \multirow[b]{2}{*}{ Outcome } & \multicolumn{6}{|c|}{ Cognitive Domain Level of Achievement } \\
\hline & $\begin{array}{c}\text { Level } 1 \\
\text { Remember }\end{array}$ & $\begin{array}{c}\text { Level } 2 \\
\text { Comprehend }\end{array}$ & $\begin{array}{l}\text { Level } 3 \\
\text { Apply }\end{array}$ & $\begin{array}{l}\text { Level } 4 \\
\text { Analyze }\end{array}$ & $\begin{array}{c}\text { Level } 5 \\
\text { Synthesize }\end{array}$ & $\begin{array}{l}\text { Level } 6 \\
\text { Evaluate }\end{array}$ \\
\hline $\begin{array}{l}\text { Risk and } \\
\text { Uncertainty }\end{array}$ & $\begin{array}{l}\text { Identify concepts } \\
\text { and principles of } \\
\text { probability, statistics } \\
\text { and risk relevant to } \\
\text { civil engineering. } \\
\text { (UG) }\end{array}$ & $\begin{array}{l}\text { Explain concepts } \\
\text { and principles of } \\
\text { probability, statistics } \\
\text { and risk relevant to } \\
\text { civil engineering. } \\
\text { (UG) }\end{array}$ & $\begin{array}{l}\text { Apply concepts and } \\
\text { principles of } \\
\text { probability and } \\
\text { statistics and } \\
\text { determine risk } \\
\text { relevant to civil } \\
\text { engineering. (UG) }\end{array}$ & $\begin{array}{l}\text { Select appropriate } \\
\text { concepts and } \\
\text { principles of } \\
\text { probability and } \\
\text { statistics and } \\
\text { analyze risk in } \\
\text { complex civil } \\
\text { engineering } \\
\text { problems. (ME) }\end{array}$ & $\begin{array}{l}\text { Integrate risk } \\
\text { analyses into the } \\
\text { solutions to complex } \\
\text { civil engineering } \\
\text { problems. }\end{array}$ & $\begin{array}{l}\text { Assess the } \\
\text { acceptability of the } \\
\text { risks associated with } \\
\text { solutions to complex } \\
\text { civil engineering } \\
\text { problems. }\end{array}$ \\
\hline $\begin{array}{l}\text { Breadth in Civil } \\
\text { Engineering Areas }\end{array}$ & $\begin{array}{l}\text { Identify concepts } \\
\text { and principles } \\
\text { related to at least } \\
\text { four technical areas } \\
\text { appropriate to the } \\
\text { practice of civil } \\
\text { engineering. (UG) }\end{array}$ & $\begin{array}{l}\text { Explain concepts } \\
\text { and principles } \\
\text { related to at least } \\
\text { four technical areas } \\
\text { appropriate to the } \\
\text { practice of civil } \\
\text { engineering. (UG) }\end{array}$ & $\begin{array}{l}\text { Apply concepts and } \\
\text { principles to solve } \\
\text { complex problems } \\
\text { in at least four } \\
\text { technical areas } \\
\text { appropriate to the } \\
\text { practice of civil } \\
\text { engineering. (UG) }\end{array}$ & $\begin{array}{l}\text { Analyze complex } \\
\text { problems that cross } \\
\text { multiple technical } \\
\text { areas appropriate } \\
\text { the practice of to } \\
\text { civil engineering. } \\
\text { (ME) }\end{array}$ & $\begin{array}{l}\text { Integrate solutions } \\
\text { to complex } \\
\text { problems that } \\
\text { involve multiple } \\
\text { technical areas } \\
\text { appropriate to the } \\
\text { practice of civil } \\
\text { engineering. }\end{array}$ & $\begin{array}{l}\text { Evaluate solutions } \\
\text { to complex } \\
\text { problems that } \\
\text { involve multiple } \\
\text { technical areas } \\
\text { appropriate to the } \\
\text { practice of civil } \\
\text { engineering. }\end{array}$ \\
\hline Design & $\begin{array}{l}\text { Define engineering } \\
\text { design and the } \\
\text { engineering design } \\
\text { process. (UG) }\end{array}$ & $\begin{array}{l}\text { Explain engineering } \\
\text { design and the } \\
\text { engineering design } \\
\text { process. (UG) }\end{array}$ & $\begin{array}{l}\text { Formulate a set of } \\
\text { possible design } \\
\text { solutions to complex } \\
\text { civil engineering } \\
\text { problems. (UG) }\end{array}$ & $\begin{array}{l}\text { Analyze a set of } \\
\text { possible design } \\
\text { solutions to complex } \\
\text { civil engineering } \\
\text { problems. (ME) }\end{array}$ & $\begin{array}{l}\text { Develop the most } \\
\text { appropriate } \\
\text { sustainable design } \\
\text { solution to complex } \\
\text { civil engineering } \\
\text { problems. (ME) }\end{array}$ & $\begin{array}{l}\text { Assess the most } \\
\text { appropriate } \\
\text { sustainable design } \\
\text { solution to complex } \\
\text { civil engineering } \\
\text { problems. }\end{array}$ \\
\hline Technical Depth & $\begin{array}{l}\text { Define advanced } \\
\text { concepts and } \\
\text { principles related to } \\
\text { a technical area } \\
\text { appropriate to the } \\
\text { practice of civil } \\
\text { engineering. (UG) }\end{array}$ & $\begin{array}{l}\text { Explain advanced } \\
\text { concepts and } \\
\text { principles related to } \\
\text { a technical area } \\
\text { appropriate to the } \\
\text { practice of civil } \\
\text { engineering. (UG) }\end{array}$ & $\begin{array}{l}\text { Apply advanced } \\
\text { concepts and } \\
\text { principles and solve } \\
\text { complex problems } \\
\text { in a technical area } \\
\text { appropriate to the } \\
\text { practice of civil } \\
\text { engineering. (PG) }\end{array}$ & $\begin{array}{l}\text { Select appropriate } \\
\text { advanced concepts } \\
\text { and principles to } \\
\text { solve complex } \\
\text { problems in a } \\
\text { technical area } \\
\text { appropriate to the } \\
\text { practice of civil } \\
\text { engineering. (PG) }\end{array}$ & $\begin{array}{l}\text { Integrate advanced } \\
\text { concepts and } \\
\text { principles into the } \\
\text { solutions of complex } \\
\text { problems in a } \\
\text { technical area } \\
\text { appropriate to the } \\
\text { practice of civil } \\
\text { engineering. (ME) }\end{array}$ & $\begin{array}{l}\text { Assess advanced } \\
\text { concepts and } \\
\text { principles in the } \\
\text { solutions of complex } \\
\text { problems in a } \\
\text { technical area } \\
\text { appropriate to the } \\
\text { practice of civil } \\
\text { engineering. }\end{array}$ \\
\hline
\end{tabular}




\begin{tabular}{|c|c|c|c|c|c|c|}
\hline \multirow[b]{2}{*}{ Outcome } & \multicolumn{6}{|c|}{ Cognitive Domain Level of Achievement } \\
\hline & $\begin{array}{c}\text { Level } 1 \\
\text { Remember }\end{array}$ & $\begin{array}{c}\text { Level } 2 \\
\text { Comprehend }\end{array}$ & $\begin{array}{l}\text { Level } 3 \\
\text { Apply }\end{array}$ & $\begin{array}{c}\text { Level } 4 \\
\text { Analyze }\end{array}$ & $\begin{array}{c}\text { Level } 5 \\
\text { Synthesize }\end{array}$ & $\begin{array}{c}\text { Level } 6 \\
\text { Evaluate }\end{array}$ \\
\hline Sustainability & $\begin{array}{l}\text { Identify concepts } \\
\text { and principles of } \\
\text { sustainability. (UG) }\end{array}$ & $\begin{array}{l}\text { Explain concepts } \\
\text { and principles of } \\
\text { sustainability. (UG) }\end{array}$ & $\begin{array}{l}\text { Apply concepts and } \\
\text { principles of } \\
\text { sustainability to the } \\
\text { solution of civil } \\
\text { engineering } \\
\text { problems. (UG) }\end{array}$ & $\begin{array}{l}\text { Analyze the } \\
\text { sustainable } \\
\text { performance of civil } \\
\text { engineering } \\
\text { systems. (ME) }\end{array}$ & $\begin{array}{l}\text { Develop practices } \\
\text { and requirements to } \\
\text { achieve sustainable } \\
\text { solutions to complex } \\
\text { civil engineering } \\
\text { problems. }\end{array}$ & $\begin{array}{l}\text { Assess practices and } \\
\text { requirements to } \\
\text { achieve sustainable } \\
\text { solutions to } \\
\text { complex civil } \\
\text { engineering } \\
\text { problems. }\end{array}$ \\
\hline Communication & $\begin{array}{l}\text { Identify concepts } \\
\text { and principles of } \\
\text { effective } \\
\text { communications for } \\
\text { technical and non- } \\
\text { technical audiences. } \\
\text { (UG) }\end{array}$ & $\begin{array}{l}\text { Explain concepts } \\
\text { and principles of } \\
\text { effective } \\
\text { communications for } \\
\text { technical and non- } \\
\text { technical audiences. } \\
\text { (UG) }\end{array}$ & $\begin{array}{l}\text { Formulate effective } \\
\text { communications for } \\
\text { technical and non- } \\
\text { technical audiences. } \\
\text { (UG) }\end{array}$ & $\begin{array}{l}\text { Analyze effective } \\
\text { communications for } \\
\text { technical and non- } \\
\text { technical audiences. } \\
\text { (ME) }\end{array}$ & $\begin{array}{l}\text { Integrate different } \\
\text { forms of effective } \\
\text { communication for } \\
\text { technical and non- } \\
\text { technical audiences. } \\
\text { (ME) }\end{array}$ & $\begin{array}{l}\text { Assess the } \\
\text { effectiveness of } \\
\text { communication for } \\
\text { technical and non- } \\
\text { technical audiences. }\end{array}$ \\
\hline $\begin{array}{l}\text { Teamwork and } \\
\text { Leadership }\end{array}$ & $\begin{array}{l}\text { Identify concepts } \\
\text { and principles of } \\
\text { teamwork and } \\
\text { leadership, including } \\
\text { diversity and } \\
\text { inclusion. (UG) }\end{array}$ & $\begin{array}{l}\text { Explain concepts } \\
\text { and principles of } \\
\text { teamwork and } \\
\text { leadership, including } \\
\text { diversity and } \\
\text { inclusion. (UG) }\end{array}$ & $\begin{array}{l}\text { Apply concepts and } \\
\text { principles of } \\
\text { teamwork and } \\
\text { leadership in the } \\
\text { solutions of civil } \\
\text { engineering } \\
\text { problems. (UG) }\end{array}$ & $\begin{array}{l}\text { Select concepts and } \\
\text { principles of } \\
\text { effective teamwork } \\
\text { and leadership in } \\
\text { the solutions of civil } \\
\text { engineering } \\
\text { problems. (ME) }\end{array}$ & $\begin{array}{l}\text { Integrate concepts } \\
\text { and principles of } \\
\text { effective teamwork } \\
\text { and leadership, } \\
\text { including diversity } \\
\text { and inclusion, into } \\
\text { the solutions of civil } \\
\text { engineering } \\
\text { problems. (ME) }\end{array}$ & $\begin{array}{l}\text { Evaluate the } \\
\text { effectiveness of } \\
\text { leaders and teams in } \\
\text { the solution of civil } \\
\text { engineering } \\
\text { problems. }\end{array}$ \\
\hline Lifelong Learning & $\begin{array}{l}\text { Identify the need } \\
\text { for additional } \\
\text { knowledge, skills, } \\
\text { and attitudes to be } \\
\text { acquired through } \\
\text { self-directed } \\
\text { learning. (UG) }\end{array}$ & $\begin{array}{l}\text { Explain the need for } \\
\text { additional } \\
\text { knowledge, skills, } \\
\text { and attitudes to be } \\
\text { acquired through } \\
\text { self-directed } \\
\text { learning. (UG) }\end{array}$ & $\begin{array}{l}\text { Acquire new } \\
\text { knowledge, skills, } \\
\text { and attitudes } \\
\text { relevant to civil } \\
\text { engineering through } \\
\text { self-directed } \\
\text { learning. (UG) }\end{array}$ & $\begin{array}{l}\text { Analyze new } \\
\text { knowledge, skills, } \\
\text { and attitudes } \\
\text { relevant to civil } \\
\text { engineering } \\
\text { acquired through } \\
\text { self-directed } \\
\text { learning. (ME) }\end{array}$ & $\begin{array}{l}\text { Integrate new } \\
\text { knowledge, skills, } \\
\text { and attitudes } \\
\text { acquired through } \\
\text { self-directed } \\
\text { learning into the } \\
\text { practice of civil } \\
\text { engineering. (ME) }\end{array}$ & $\begin{array}{l}\text { Evaluate the } \\
\text { effectiveness of the } \\
\text { additional } \\
\text { knowledge, skills, } \\
\text { and attitudes } \\
\text { acquired through } \\
\text { self-directed } \\
\text { learning. }\end{array}$ \\
\hline
\end{tabular}




\begin{tabular}{|c|c|c|c|c|c|c|}
\hline \multirow[b]{2}{*}{ Outcome } & \multicolumn{6}{|c|}{ Cognitive Domain Level of Achievement } \\
\hline & $\begin{array}{c}\text { Level } 1 \\
\text { Remember }\end{array}$ & $\begin{array}{c}\text { Level } 2 \\
\text { Comprehend }\end{array}$ & $\begin{array}{l}\text { Level } 3 \\
\text { Apply }\end{array}$ & $\begin{array}{l}\text { Level } 4 \\
\text { Analyze }\end{array}$ & $\begin{array}{c}\text { Level } 5 \\
\text { Synthesize }\end{array}$ & $\begin{array}{c}\text { Level } 6 \\
\text { Evaluate }\end{array}$ \\
\hline $\begin{array}{l}\text { Professional } \\
\text { Attitudes }\end{array}$ & $\begin{array}{l}\text { Identify } \\
\text { professional } \\
\text { attitudes including } \\
\text { creativity, curiosity, } \\
\text { flexibility, and } \\
\text { dependability in the } \\
\text { practice of civil } \\
\text { engineering. (UG) }\end{array}$ & $\begin{array}{l}\text { Explain professional } \\
\text { attitudes including } \\
\text { creativity, curiosity, } \\
\text { flexibility, and } \\
\text { dependability in the } \\
\text { practice of civil } \\
\text { engineering. (UG) }\end{array}$ & $\begin{array}{l}\text { Apply knowledge of } \\
\text { professional } \\
\text { attitudes including } \\
\text { creativity, curiosity, } \\
\text { flexibility, and } \\
\text { dependability in the } \\
\text { practice of civil } \\
\text { engineering. (ME) }\end{array}$ & $\begin{array}{l}\text { Illustrate } \\
\text { professional } \\
\text { attitudes including } \\
\text { creativity, curiosity, } \\
\text { flexibility, and } \\
\text { dependability in the } \\
\text { practice of civil } \\
\text { engineering. (ME) }\end{array}$ & $\begin{array}{l}\text { Integrate } \\
\text { professional } \\
\text { attitudes including } \\
\text { creativity, curiosity, } \\
\text { flexibility, and } \\
\text { dependability in } \\
\text { the practice of civil } \\
\text { engineering. }\end{array}$ & $\begin{array}{l}\text { Assess professional } \\
\text { attitudes including } \\
\text { creativity, curiosity, } \\
\text { flexibility, and } \\
\text { dependability in the } \\
\text { practice of civil } \\
\text { engineering. }\end{array}$ \\
\hline $\begin{array}{l}\text { Professional } \\
\text { Responsibilities }\end{array}$ & $\begin{array}{l}\text { Identify } \\
\text { professional } \\
\text { responsibilities } \\
\text { relevant to the } \\
\text { practice of civil } \\
\text { engineering, } \\
\text { including safety, } \\
\text { legal issues, } \\
\text { licensure, } \\
\text { credentialing, and } \\
\text { innovation. (UG) }\end{array}$ & $\begin{array}{l}\text { Explain professional } \\
\text { responsibilities } \\
\text { relevant to the } \\
\text { practice of civil } \\
\text { engineering, } \\
\text { including safety, } \\
\text { legal issues, } \\
\text { licensure, } \\
\text { credentialing, and } \\
\text { innovation. (UG) }\end{array}$ & $\begin{array}{l}\text { Apply professional } \\
\text { responsibilities } \\
\text { relevant to the } \\
\text { practice of civil } \\
\text { engineering, } \\
\text { including safety, } \\
\text { legal issues, } \\
\text { licensure, } \\
\text { credentialing, and } \\
\text { innovation. (ME) }\end{array}$ & $\begin{array}{l}\text { Illustrate } \\
\text { professional } \\
\text { responsibilities } \\
\text { relevant to the } \\
\text { practice of civil } \\
\text { engineering, } \\
\text { including safety, } \\
\text { legal issues, } \\
\text { licensure, } \\
\text { credentialing, and } \\
\text { innovation. (ME) }\end{array}$ & $\begin{array}{l}\text { Integrate } \\
\text { professional } \\
\text { responsibilities } \\
\text { relevant to the } \\
\text { practice of civil } \\
\text { engineering, } \\
\text { including safety, } \\
\text { legal issues, } \\
\text { licensure, } \\
\text { credentialing, and } \\
\text { innovation. (ME) }\end{array}$ & $\begin{array}{l}\text { Assess professional } \\
\text { responsibilities } \\
\text { relevant to the } \\
\text { practice of civil } \\
\text { engineering, } \\
\text { including safety, legal } \\
\text { issues, licensure, } \\
\text { credentialing, and } \\
\text { innovation. }\end{array}$ \\
\hline $\begin{array}{l}\text { Ethical } \\
\text { Responsibilities }\end{array}$ & $\begin{array}{l}\text { Identify the ethical } \\
\text { responsibilities of a } \\
\text { civil engineer in } \\
\text { accordance with the } \\
\text { ASCE Code of Ethics } \\
\text { and statutory } \\
\text { requirements. (UG) }\end{array}$ & $\begin{array}{l}\text { Explain the ethical } \\
\text { responsibilities of a } \\
\text { civil engineer in } \\
\text { accordance with the } \\
\text { ASCE Code of Ethics } \\
\text { and statutory } \\
\text { requirements. (UG) }\end{array}$ & $\begin{array}{l}\text { Apply appropriate } \\
\text { ethical } \\
\text { requirements to a } \\
\text { situation involving } \\
\text { conflicting ethical } \\
\text { interests. (ME) }\end{array}$ & $\begin{array}{l}\text { Analyze ethical } \\
\text { dilemmas involving } \\
\text { conflicting ethical } \\
\text { interests to } \\
\text { determine possible } \\
\text { courses of action. } \\
\text { (ME) }\end{array}$ & $\begin{array}{l}\text { Develop courses of } \\
\text { action to ethical } \\
\text { dilemmas in } \\
\text { complex situations } \\
\text { involving multiple } \\
\text { conflicting } \\
\text { interests. (ME) }\end{array}$ & $\begin{array}{l}\text { Assess ethical } \\
\text { dilemmas in a } \\
\text { complex situation } \\
\text { involving multiple } \\
\text { conflicting interests. }\end{array}$ \\
\hline
\end{tabular}


First Draft of the BOK3 Affective Domain Rubric

\begin{tabular}{|c|c|c|c|c|c|}
\hline \multirow[b]{2}{*}{ Outcome } & \multicolumn{5}{|c|}{$\begin{array}{l}\text { Affective Domain Level of Achievement } \\
\text { The affective domain describes an individual's level of internalization or sense of value for human experience, } \\
\text { to include their degree of acceptance or rejection of a concept, process or phenomenon. }\end{array}$} \\
\hline & $\begin{array}{l}\text { Level } 1 \\
\text { Receive } \\
\text { The ability to be aware of, } \\
\text { be willing to receive, and be } \\
\text { attentive to a particular } \\
\text { phenomenon or behavior. }\end{array}$ & $\begin{array}{c}\text { Level } 2 \\
\text { Respond } \\
\text { The ability to actively } \\
\text { participate in an activity, } \\
\text { attend to a task, and react } \\
\text { to motivation. }\end{array}$ & $\begin{array}{l}\text { Level } 3 \\
\text { Value } \\
\text { The ability to attach value } \\
\text { to a particular object, } \\
\text { phenomenon, or behavior. }\end{array}$ & $\begin{array}{c}\text { Level } 4 \\
\text { Organize } \\
\text { The ability to sort values into } \\
\text { priorities by contrasting } \\
\text { different values, resolving } \\
\text { conflicts between them, and } \\
\text { creating a unique value } \\
\text { system. }\end{array}$ & $\begin{array}{c}\text { Level } 5 \\
\text { Characterize } \\
\text { The ability to follow a value } \\
\text { system that controls } \\
\text { behavior that is pervasive, } \\
\text { consistent, predictable, and } \\
\text { a defining characteristic. }\end{array}$ \\
\hline Sustainability & $\begin{array}{l}\text { Acknowledge the } \\
\text { importance of } \\
\text { sustainability in the } \\
\text { practice of civil } \\
\text { engineering. (UG) }\end{array}$ & $\begin{array}{l}\text { Comply with the concepts } \\
\text { and principles of } \\
\text { sustainability in the } \\
\text { practice of civil } \\
\text { engineering. (UG) }\end{array}$ & $\begin{array}{l}\text { Value the benefits of } \\
\text { sustainability in the } \\
\text { practice of civil } \\
\text { engineering. (ME) }\end{array}$ & $\begin{array}{l}\text { Integrate a commitment } \\
\text { to sustainability principles } \\
\text { in everyday practice. (SD) }\end{array}$ & $\begin{array}{l}\text { Advocate for principles } \\
\text { of sustainability. }\end{array}$ \\
\hline Communication & $\begin{array}{l}\text { Acknowledge the } \\
\text { importance of effective } \\
\text { and persuasive } \\
\text { communication to } \\
\text { technical and } \\
\text { nontechnical audiences. } \\
\text { (UG) }\end{array}$ & $\begin{array}{l}\text { Practice effective and } \\
\text { persuasive } \\
\text { communication to } \\
\text { technical and } \\
\text { nontechnical audiences. } \\
\text { (UG) }\end{array}$ & $\begin{array}{l}\text { Value effective and } \\
\text { persuasive } \\
\text { communication to } \\
\text { technical and } \\
\text { nontechnical audiences. } \\
\text { (ME) }\end{array}$ & $\begin{array}{l}\text { Display effective and } \\
\text { persuasive } \\
\text { communication to } \\
\text { technical and } \\
\text { nontechnical audiences. } \\
\text { (SD) }\end{array}$ & $\begin{array}{l}\text { Advocate for effective } \\
\text { and persuasive } \\
\text { communication to } \\
\text { technical and } \\
\text { nontechnical audiences. }\end{array}$ \\
\hline $\begin{array}{l}\text { Teamwork and } \\
\text { Leadership }\end{array}$ & $\begin{array}{l}\text { Acknowledge the } \\
\text { importance of } \\
\text { teamwork, leadership, } \\
\text { diversity and inclusion. } \\
\text { (UG) }\end{array}$ & $\begin{array}{l}\text { Practice concepts and } \\
\text { principles of teamwork, } \\
\text { leadership, diversity and } \\
\text { inclusion. (UG) }\end{array}$ & $\begin{array}{l}\text { Value the need for } \\
\text { teamwork, leadership, } \\
\text { diversity and inclusion. } \\
\text { (ME) }\end{array}$ & $\begin{array}{l}\text { Display effective } \\
\text { teamwork and } \\
\text { leadership, including } \\
\text { support of diversity and } \\
\text { inclusion. (SD) }\end{array}$ & $\begin{array}{l}\text { Advocate for teamwork } \\
\text { and leadership, diversity } \\
\text { and inclusion. }\end{array}$ \\
\hline Lifelong Learning & $\begin{array}{l}\text { Acknowledge the need } \\
\text { for lifelong learning. } \\
\text { (UG) }\end{array}$ & $\begin{array}{l}\text { Participate in lifelong } \\
\text { learning opportunities. } \\
\text { (UG) }\end{array}$ & $\begin{array}{l}\text { Value lifelong learning in } \\
\text { the practice of civil } \\
\text { engineering. (ME) }\end{array}$ & $\begin{array}{l}\text { Establish a lifelong } \\
\text { learning plan to support } \\
\text { one's own professional } \\
\text { development. (SD) }\end{array}$ & $\begin{array}{l}\text { Advocate for lifelong } \\
\text { learning in the practice } \\
\text { of civil engineering. }\end{array}$ \\
\hline
\end{tabular}




\begin{tabular}{|c|c|c|c|c|c|}
\hline Outcome & \multicolumn{5}{|c|}{ Affective Domain Level of Achievement } \\
\hline $\begin{array}{l}\text { Professional } \\
\text { Responsibilities }\end{array}$ & $\begin{array}{l}\text { Acknowledge } \\
\text { professional } \\
\text { responsibilities relevant } \\
\text { to the practice of civil } \\
\text { engineering, including } \\
\text { safety, legal issues, } \\
\text { licensure, credentialing, } \\
\text { and innovation. (UG) }\end{array}$ & $\begin{array}{l}\text { Examine professional } \\
\text { responsibilities relevant } \\
\text { to the practice of civil } \\
\text { engineering, including } \\
\text { safety, legal issues, } \\
\text { licensure, credentialing, } \\
\text { and innovation. (UG) }\end{array}$ & $\begin{array}{l}\text { Value professional } \\
\text { responsibilities relevant } \\
\text { to the practice of civil } \\
\text { engineering, including } \\
\text { safety, legal issues, } \\
\text { licensure, credentialing, } \\
\text { and innovation. (ME) }\end{array}$ & $\begin{array}{l}\text { Form judgements about } \\
\text { professional } \\
\text { responsibilities relevant } \\
\text { to the practice of civil } \\
\text { engineering, including } \\
\text { safety, legal issues, } \\
\text { licensure, credentialing, } \\
\text { and innovation. (SD) }\end{array}$ & $\begin{array}{l}\text { Advocate for } \\
\text { professional } \\
\text { responsibilities relevant } \\
\text { to the practice of civil } \\
\text { engineering, including } \\
\text { safety, legal issues, } \\
\text { licensure, credentialing, } \\
\text { and innovation. }\end{array}$ \\
\hline
\end{tabular}




\section{Definitions of Verbs Used in the BOK3 Affective Domain Rubric}

\begin{tabular}{|c|c|c|c|c|c|}
\hline & \multicolumn{5}{|c|}{ Affective Domain Level of Achievement } \\
\hline & $\begin{array}{l}\text { Level } 1 \\
\text { Receive }\end{array}$ & $\begin{array}{l}\text { Level } 2 \\
\text { Respond }\end{array}$ & $\begin{array}{l}\text { Level } 3 \\
\text { Value }\end{array}$ & $\begin{array}{c}\text { Level } 4 \\
\text { Organize }\end{array}$ & $\begin{array}{c}\text { Level } 5 \\
\text { Characterize }\end{array}$ \\
\hline $\begin{array}{l}\text { Definitions for the } \\
\text { Verbs Used in the } \\
\text { Affective Domain }\end{array}$ & $\begin{array}{l}\text { Acknowledge: to admit } \\
\text { to be real or true; } \\
\text { recognize the existence, } \\
\text { truth, or fact of. }\end{array}$ & $\begin{array}{l}\text { Comply: to act or be in } \\
\text { accordance with wishes, } \\
\text { requests, demands, } \\
\text { requirements, } \\
\text { conditions, etc. } \\
\text { Examine: put to } \\
\text { question in regard to } \\
\text { conduct or knowledge of } \\
\text { facts. } \\
\text { Participate: to take or } \\
\text { have a part or share in, } \\
\text { as with others. } \\
\text { Practice: to perform } \\
\text { repeatedly in order to } \\
\text { acquire skill or } \\
\text { proficiency. }\end{array}$ & $\begin{array}{l}\text { Value: to consider with } \\
\text { respect to worth, } \\
\text { excellence, usefulness, } \\
\text { or importance. }\end{array}$ & $\begin{array}{l}\text { Adhere to: to hold closely } \\
\text { or firmly. } \\
\text { Display: to show or } \\
\text { exhibit; to show } \\
\text { ostentatiously; flaunt. } \\
\text { Establish: to enact, or } \\
\text { cause to be accepted or } \\
\text { recognized; to bring } \\
\text { about permanently. } \\
\text { Form Judgements: to } \\
\text { make decisions or form } \\
\text { opinions objectively, } \\
\text { authoritatively. } \\
\text { Integrate: to meld with } \\
\text { and become part of the } \\
\text { dominant culture. }\end{array}$ & $\begin{array}{l}\text { Advocate for: to speak } \\
\text { or write in favor of; } \\
\text { support or urge } \\
\text { argument; recommend } \\
\text { publicly }\end{array}$ \\
\hline
\end{tabular}




\section{Appendix II: Examples of Draft BOK3 Outcome Explanations}

Draft explanations were developed for each outcome and will be included in the main body of the final BOK3 report. Two example draft explanations are provided in this appendix. 


\section{Draft Explanation for BOK3 Design Outcome}

\begin{tabular}{|l|l|l|}
\hline $\begin{array}{l}\text { Cognitive Domain } \\
\text { Level of Achievement }\end{array}$ & Demonstrated Ability & $\begin{array}{l}\text { Fulfilled } \\
\text { Through }\end{array}$ \\
\hline $\begin{array}{l}\text { 1- Remember } \\
\text { (remember previously learned } \\
\text { material) }\end{array}$ & $\begin{array}{l}\text { Define engineering design and the } \\
\text { engineering design process. }\end{array}$ & $\begin{array}{l}\text { Undergraduate } \\
\text { Education }\end{array}$ \\
\hline $\begin{array}{l}\text { - Comprehend } \\
\text { grasp the meaning of learned } \\
\text { material) }\end{array}$ & $\begin{array}{l}\text { Explain engineering design and the } \\
\text { engineering design process. }\end{array}$ & $\begin{array}{l}\text { Undergraduate } \\
\text { Education }\end{array}$ \\
\hline $\begin{array}{l}\text { 3-Apply } \\
\text { (use learned material in new and } \\
\text { concrete situations) }\end{array}$ & $\begin{array}{l}\text { Formulate a set of possible design solutions } \\
\text { to complex civil engineering problems. }\end{array}$ & $\begin{array}{l}\text { Undergraduate } \\
\text { Education }\end{array}$ \\
\hline $\begin{array}{l}\text { 4- Analyze } \\
\text { (break down learned material into } \\
\text { its component parts so that its } \\
\text { organizational structure may be } \\
\text { understood) }\end{array}$ & $\begin{array}{l}\text { Analyze a set of possible design solutions to } \\
\text { complex civil engineering problems. }\end{array}$ & $\begin{array}{l}\text { Mentored } \\
\text { Experience }\end{array}$ \\
\hline $\begin{array}{l}\text { 5- Synthesize } \\
\text { (put learned material together to } \\
\text { form a new whole) }\end{array}$ & $\begin{array}{l}\text { Develop the most appropriate sustainable } \\
\text { design solution to complex civil engineering } \\
\text { problems. }\end{array}$ & $\begin{array}{l}\text { Mentored } \\
\text { Experience }\end{array}$ \\
\hline $\begin{array}{l}\text { 6- Evaluate } \\
\text { (judge the value of learned } \\
\text { material for a given purpose) }\end{array}$ & $\begin{array}{l}\text { Assess the most appropriate sustainable design } \\
\text { solution to complex civil engineering problems. }\end{array}$ & \\
\hline
\end{tabular}

\section{Understanding the Outcome}

Design is a decision making process, often iterative, in which basic science, mathematics and engineering science are applied to convert resources optimally to meet a stated need. Such activities as problem definition, specifying requirements, the selection or development of design options, analysis, detailed design, performance prediction, implementation, observation, and testing are all parts of the engineering design process. Design problems are often ill-defined. Thus defining the scope and design objectives and identifying the constraints governing a particular problem are essential to the design process.

\section{Rationale}

"Science is about knowing; engineering is about doing." ${ }^{a}$ Engineers combine science, math, technology, and creativity to create solutions to problems and develop products. In fact, the essence of civil engineering is the iterative process of designing, predicting performance, building, and testing. The design process is open-ended and involves a number of possible correct solutions, including innovative approaches. Thus successful design requires application fundamentals in basic science, math and engineering science, detailed knowledge of the design process, critical thinking, an appreciation of the uncertainties involved, and the use of engineering judgment.

a Petroski, H. (2010) The Essential Engineer: Why Science Alone Will Not Solve Our Global Problems, Knoph Pub, p 228. 


\section{Level of Achievement}

Design encompasses fundamental concepts and principles used to solve problems with realistic constraints and standards. For entry into the practice of civil engineering at the professional level all civil engineers should be at the synthesis level. Such considerations as risk assessment, societal and environmental impact, standards, codes, regulations, safety, security, sustainability, constructability, and operability must be integrated at various stages of the design process. A breadth of technical knowledge in several recognized and/or emerging areas of the civil engineering discipline is necessary for understanding the relationship and interaction of different elements in a designed system or environment.

\section{Fulfillment of the Outcome}

The National Academy of Engineering recommends that the design process be introduced to students from the "earliest stages of the curriculum, including the first year." Fostering creative knowledge in students prepares them to handle a future of increasing complexity that relies on a multidisciplinary approach to solving problems. ${ }^{\mathrm{c}}$ The design component in the baccalaureate curriculum should involve application of the design process under a defined set of standards and constraints. Mentored experience should include opportunities to employ many or all aspects of the design process, including problem definition, project planning, scoping, the design objective, the development of design options, adherence to codes regulations and standards, economy, safety, constructability, operability, and sustainability. Experience at this level should include familiarity with interactions between planning, design, construction and operations and should take into account design life-cycle assessment.

b National Academy of Engineering. (2004) The Engineer of 2020: Adapting Engineering Education to the New Century, The National Academies of Sciences, Washington, D.C.

c Parcover, J.A. and R.H. McCuen. (1995) “Discovery Approach to Teaching Engineering Design”, Journal of Professional Issues in Education and Practice, ASCE, Vol. 121, No. 4 pp.236-241 


\section{Draft Explanation for BOK3 Communication Outcome}

\begin{tabular}{|c|c|c|}
\hline $\begin{array}{l}\text { Cognitive Domain } \\
\text { Level of Achievement }\end{array}$ & Demonstrated Ability & $\begin{array}{l}\text { Fulfilled } \\
\text { Through } \\
\end{array}$ \\
\hline $\begin{array}{l}1-\text { Remember } \\
\text { (remember previously learned } \\
\text { material) }\end{array}$ & $\begin{array}{l}\text { Identify concepts and principles of effective } \\
\text { communications for technical and non- } \\
\text { technical audiences. }\end{array}$ & $\begin{array}{l}\text { Undergraduate } \\
\text { Education }\end{array}$ \\
\hline $\begin{array}{l}2-\text { Comprehend } \\
\text { (grasp the meaning of learned } \\
\text { material) }\end{array}$ & $\begin{array}{l}\text { Explain concepts and principles of effective } \\
\text { communications for technical and non- } \\
\text { technical audiences. }\end{array}$ & $\begin{array}{l}\text { Undergraduate } \\
\text { Education }\end{array}$ \\
\hline $\begin{array}{l}3 \text { - Apply } \\
\text { (use learned material in new and } \\
\text { concrete situations) }\end{array}$ & $\begin{array}{l}\text { Formulate effective communications for } \\
\text { technical and non-technical audiences. }\end{array}$ & $\begin{array}{l}\text { Undergraduate } \\
\text { Education }\end{array}$ \\
\hline $\begin{array}{l}4-\text { Analyze } \\
\text { (break down learned material into } \\
\text { its component parts so that its } \\
\text { organizational structure may be } \\
\text { understood) }\end{array}$ & $\begin{array}{l}\text { Analyze effective communications for } \\
\text { technical and non-technical audiences. }\end{array}$ & $\begin{array}{l}\text { Mentored } \\
\text { Experience }\end{array}$ \\
\hline $\begin{array}{l}5 \text { - Synthesize } \\
\text { (put learned material together to } \\
\text { form a new whole) }\end{array}$ & $\begin{array}{l}\text { Integrate different forms of effective } \\
\text { communication for technical and non- } \\
\text { technical audiences. }\end{array}$ & $\begin{array}{l}\text { Mentored } \\
\text { Experience }\end{array}$ \\
\hline $\begin{array}{l}6-\text { Evaluate } \\
\text { (judge the value of learned } \\
\text { material for a given purpose) }\end{array}$ & $\begin{array}{l}\text { Assess the effectiveness of communication for } \\
\text { technical and non-technical audiences. }\end{array}$ & \\
\hline
\end{tabular}

\begin{tabular}{|l|l|l|}
\hline $\begin{array}{l}\text { Affective Domain } \\
\text { Level of Achievement }\end{array}$ & Demonstrated Ability & $\begin{array}{l}\text { Fulfilled } \\
\text { Through }\end{array}$ \\
\hline $\begin{array}{l}\text { 1- Receive } \\
\text { (be aware of, be willing to } \\
\text { receive, and be attentive to a } \\
\text { particular phenomenon or } \\
\text { behavior) }\end{array}$ & $\begin{array}{l}\text { Acknowledge the importance of effective } \\
\text { and persuasive communication to technical } \\
\text { and nontechnical audiences. }\end{array}$ & $\begin{array}{l}\text { Undergraduate } \\
\text { Education }\end{array}$ \\
\hline $\begin{array}{l}\text { (actively participate in an activity, } \\
\text { attend to a task, and react to } \\
\text { motivation) }\end{array}$ & $\begin{array}{l}\text { Practice effective and persuasive } \\
\text { communication to technical and } \\
\text { nontechnical audiences. }\end{array}$ & $\begin{array}{l}\text { Undergraduate } \\
\text { Education }\end{array}$ \\
\hline $\begin{array}{l}\text { 3- Value } \\
\text { attach value to a particular object, } \\
\text { phenomenon, or behavior) }\end{array}$ & $\begin{array}{l}\text { Value effective and persuasive } \\
\text { communication to technical and } \\
\text { nontechnical audiences. }\end{array}$ & $\begin{array}{l}\text { Mentored } \\
\text { Experience }\end{array}$ \\
\hline $\begin{array}{l}4-\text { Organize } \\
\text { (sort values into priorities by } \\
\text { contrasting different values, } \\
\text { resolving conflicts between them, } \\
\text { and creating a unique value } \\
\text { system) }\end{array}$ & $\begin{array}{l}\text { Display effective and persuasive } \\
\text { communication to technical and } \\
\text { nontechnical audiences. }\end{array}$ & $\begin{array}{l}\text { Self- } \\
\text { Developed }\end{array}$ \\
\hline $\begin{array}{l}\text { 5-Characterize } \\
\text { (follow a value system that } \\
\text { controls behavior that is } \\
\text { pervasive, consistent, predictable, } \\
\text { and a defining characteristic) }\end{array}$ & $\begin{array}{l}\text { Advocate for effective and persuasive } \\
\text { communication to technical and nontechnical } \\
\text { audiences. }\end{array}$ & \\
\hline
\end{tabular}




\section{Understanding the Outcome}

Forms of communication include, but is not limited to, listening, observing, reading, speaking, writing, non-verbal, visual, and graphical. Civil engineers should be acquainted with the tools used to communicate their work. The civil engineer must communicate effectively and persuasively with technical and nontechnical audiences in a variety of settings using formal and informal means.

Effective communication accurately conveys information clearly, correctly, and succinctly. Effective communication includes not only the skills to transmit information, but also to verify that the receiver has correctly understood the information. In a global setting, civil engineers must have sufficient knowledge of other cultures to effectively communicate the intended message. ${ }^{\mathrm{a}}$

Persuasive communication shapes, reinforces, or changes the response of the receiver. ${ }^{b}$ While all communication can persuade, it is important for civil engineers to know how to communicate in a manner intentionally designed to persuade others. Persuasive communication leads to a noticeable response and action by the receiver, not just an acknowledgement of the information presented. Not all communication by civil engineers is intended to be persuasive. Civil engineers can often communicate with the intent solely to transmit information. But when persuasion is needed, for example when asking for action from a city council, civil engineers must be knowledgeable and adept in the skills of persuasive communication.

\section{$\underline{\text { Rationale }}$}

Proper communication is essential to the success of the civil engineer and their work. The focus of this outcome is on developing communication skills that are effective and persuasive. High performing civil engineers are better communicators and enjoy greater career success. Strong communication skills are key attributes associated with highperforming civil engineers who enjoy greater success.

Civil engineers are more effective communicators when they value the need for accurate, succinct, and persuasive communication using appropriate forms. An appreciation of the receiver's perspective is also essential for the communication to be effective and persuasive. This appreciation is particularly important when communicating with diverse stakeholders and communicating technical issues to non-technical audiences.

\section{Level of Achievement}

Cognitive Domain: When civil engineers present information, they integrate multiple forms of effective communication appropriate for the audience, such as listening, observing, speaking, writing, non-verbal, visual, and graphical. For entry into the practice of civil engineering at the professional level, all civil engineers should be at the synthesis level and have the ability to "integrate different forms of effective communication for technical and non-technical audiences."

\footnotetext{
a American Association of Engineering Societies (AAES). (2015). Engineering Competency Model. Accessed January 15, 2018. http://www.aaes.org/model.

b Stiff, J. B., and Mongeau, P. A. (2016). Persuasive communication, $3^{\text {rd }}$ Edition. Guilford Publications.
} 
Affective Domain: Civil engineers recognize the importance of effective and persuasive communication as part of their value system for professional practice. The importance that the civil engineer attaches to communication should manifest itself in efforts to improve communication through self-development. For entry into the practice of civil engineering at the professional level, all civil engineers should be at the organize level and have the ability to "display effective and persuasive communication to technical and nontechnical audiences."

\section{Fulfillment of the Outcome}

Cognitive Domain: In the cognitive domain, the communications outcome is expected to be fulfilled through a combination of undergraduate education and mentored experience. The undergraduate experience provides many and varied opportunities to present and apply communication fundamentals. Communication can be taught and learned across the curriculum - that is, over many years of formal education and in most courses. Given the many and varied communication means, communication fundamentals and application can be woven into mathematics, science, and technical and professional practice courses as well as into humanities and social science courses. Examples include having students create graphics to explain complex systems or processes, write detailed laboratory reports for technical audiences and executive summaries for nontechnical audiences, research a topic and write a documented report, and make team presentations in capstone design courses. Such co- and extracurricular activities as cooperative education and active participation in campus organizations offer opportunities to communicate using various means in a variety of situations. In short, there are a plethora of opportunities for undergraduate civil engineering students to apply their communication skills and reach the application level. Mentored experience should build on and extend these fundamentals to solidify the civil engineer's communication skills. Engineering practice provides numerous "real-world" opportunities to analyze and synthesize communication knowledge and skills. The engineer should seek out and be encouraged by mentors to take on tasks and functions that involve ever more challenging communication. Examples of communication opportunities include drafting memoranda or reports for review by a more senior engineer, giving an internal presentation, speaking at local schools, serving on professional society committees, and making presentations at conferences and publishing the results. Mentored experience should play an integral role in helping the civil engineer reaching the analysis and synthesis levels.

Affective domain: In the affective domain, the communications outcome is expected to be fulfilled through a combination of undergraduate education, mentored experience, and selfdevelopment. At the undergraduate level, civil engineering students should acknowledge the importance of effective and persuasive communication and actively participate in communication activities. Mentored experience should help the civil engineer to place value on communication skills. Having gained a value for communication skills, through dedicated self-development engineers should further develop their effective and persuasive communication skills and demonstrate the priority that civil engineers place on these skills. 